\title{
Inherited gastrointestinal stromal tumor syndromes: mutations, clinical features, and therapeutic implications
}

\author{
Michael A Postow ${ }^{1}$ and Mark E Robson ${ }^{1,2,3^{*}}$
}

\begin{abstract}
The discovery of underlying molecular genetic abnormalities in gastrointestinal stromal tumors (GISTs) such as activating mutations in the tyrosine kinase genes, KIT and platelet derived growth factor receptor-alpha (PDGFRA), has led to remarkable clinical advances in treatment. Small molecule inhibitors such as imatinib and sunitinib are known to inhibit the aberrantly activated KIT and PDGFRA receptor signaling and can lead to excellent clinical outcomes for patients with GIST. Though the majority of GISTs appear to arise sporadically, a number of families with high frequencies of GISTs have been reported and germline mutations have been identified. This review will highlight the various inherited mutations associated with familial GIST syndromes and describe how an improved understanding of these genetic syndromes has important clinical implications for future understanding of this heterogeneous disease.
\end{abstract}

Keywords: Gastrointestinal stromal tumor, c-KIT, Platelet-derived growth factor-alpha, Neurofibromatosis, Carney triad, Carney-stratakis syndrome, Succinate dehydrogenase

\section{Introduction}

Gastrointestinal stromal tumors (GISTs) are the most common mesenchymal tumors arising in the gastrointestinal tract $[1,2]$. Though the majority of GISTs appear to arise sporadically, a number of families with high frequencies of GISTs have been reported and germline mutations have been identified [3]. The true frequency of all GIST diagnoses has been difficult to determine because the definition of GIST was derived in 1990 before it was molecularly characterized. One United States report from the Surveillance, Epidemiology, and End Results (SEER) database indicated that, from 1992 to 2000, the yearly incidence rate in the United States was 6.8 cases per million [4]. The reported US annual incidence rate is slightly lower than incidence rates reported in several international epidemiological studies with highest described incidence of 14.5 cases per million in Sweden [5-7]. Discrepancies between diagnostic criteria

\footnotetext{
* Correspondence: robsonm@mskcc.org

${ }^{1}$ Department of Medicine, Memorial Sloan-Kettering Cancer Center, New York, NY, USA

${ }^{2}$ Clinical Genetics and Breast Cancer Medicine Services, Memorial Sloan-Kettering Cancer Center, New York, NY, USA

Full list of author information is available at the end of the article
}

over the time period of data collection may have accounted for some of the variation. No specific epidemiological risk factors for GIST have been described.

The majority of GISTs appear to be sporadic, but a number of families with inherited predisposition to GISTs have been identified. The first family with features consistent with inherited GIST was reported in 1990, but it was not until 1998 that Nishida and colleagues identified the first germline mutation associated with familial predisposition to GIST [8,9]. In this Japanese family, three individuals in two generations were diagnosed with multiple GISTs. The germline DNA of the available affected family members contained a mutation in exon 11 of $c-K I T$, which resulted in deletion of a valine residue at codon 559_560 in the juxta-membrane domain of the KIT protein. This same mutation was observed in the subjects' GIST tumors and resulted in constitutive activation of KIT.

Since this first description of a family with an exon 11 KIT mutation, multiple other families with inherited GIST syndromes have been described. Though many have been found to have exon 11 KIT mutations, others have alternative KIT mutations or mutations involving

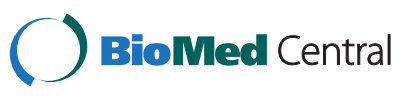

(c) 2012 Postow and Robson; licensee BioMed Central Ltd. This is an Open Access article distributed under the terms of the Creative Commons Attribution License (http://creativecommons.org/licenses/by/2.0), which permits unrestricted use, distribution, and reproduction in any medium, provided the original work is properly cited. 
PDGFRA, neurofibromatosis- 1 (NF1), and succinate dehydrogenase $(S D H)$ genes [10-29]. Similarities exist among the clinical features of these various germline familial GIST mutations, but each germline mutation can manifest differently (Table 1).

\section{C-kit mutations}

Paralleling the high frequency of KIT mutations in sporadic GIST, most reported inherited GISTs have involved families with germline mutations in the KIT gene, commonly in exon 11, which encodes the juxta-membrane domain. In addition to the development of GISTs, these families manifest variable clinical phenotypes that typically also include hyperpigmentation, urticaria pigmentosa, and dysphagia. The specific KIT exon 11 deletion mutation described in the first family with an identified germline mutation in familial GIST, does not seem to be required for the familial GIST syndrome as a similar clinical phenotype involving hyperpigmentation and GIST predisposition was seen in a Spanish family with an alternative exon 11 KIT mutation consisting of a duplication of the sequence CAACTT [30].

Missense mutations involving exon 11 have been implicated in similar familial GIST syndromes. Several families have to found with germline point mutations leading to the substitution of alanine for valine (559) in the KIT juxta-membrane domain [31]. Another exon 11 KIT juxta-membrane missense mutation (W557R) was described in a family consisting of 19 individuals of Italian ancestry who had variable expression of clinical phenotype involving hyperpigmentation and dysphagia [26]. Although the development of GIST was nearly uniform in this kindred, not all family members harboring this specific germline mutation had hyperpigmentation or dysphagia, suggesting a degree of variability of expression, even within a family with a specific KIT germline mutation.

KIT exon 11 mutations are not the only KIT mutations implicated in familial GIST syndromes. Hirota et al. (2002) reported the first identified family with a germline mutation in exon 17, encoding the KIT tyrosine kinase II domain [32]. Though the precise clinical phenotype of KIT mutations may be influenced by reporting, none of the members of this family with KIT tyrosine kinase II domain mutations had hyperpigmentation, differing from some families with KIT exon 11 mutations. Dysphagia, however, was a common similar complaint and suggests dysphagia may be a feature more characteristic of germline KIT mutations in general, rather than associated with a specific mutation.

A third KIT mutation in exon 13 encoding the tyrosine kinase I domain, has also been implicated in familial

Table 1 Germline Mutations Associated with GIST Predisposition and Associated Clinical Features

\begin{tabular}{|c|c|c|c|}
\hline Gene (Exon) & Mutation & General Clinical Features & Reference \\
\hline \multirow[t]{5}{*}{ C-KIT (11) } & V559del & Hyperpigmentation, urticaria pigmentosa, dysphagia & Nishida 1998 [9] \\
\hline & CAACTTdup & & Carballo 2005 [11] \\
\hline & V559A & & Beghini 2001 [30] \\
\hline & W557R & & Maeyama 2001 [31] \\
\hline & & & Robson 2004 [26] \\
\hline C-KIT (17) & D820Y & Dysphagia but no hyperpigmentation & Hirota 2002 [32] \\
\hline \multirow[t]{2}{*}{ C-KIT (13) } & K642E & No hyperpigmentation and no urticaria pigmentosa & Isozaki 2000 [33] \\
\hline & & & Graham 2007 [34] \\
\hline \multirow[t]{3}{*}{ PDGFRA* } & D846Y & Large hands & Chompret 2004 [35] \\
\hline & Y555C & Lipomas and small intestine fibrous tumors & de Raedt 2006 [36] \\
\hline & V561D & & Pasini 2007 [37] \\
\hline$N F 1^{* *}$ & $\begin{array}{l}\text { Many various mutations in } \\
\text { NF1 gene ( }>300 \text { identified) }\end{array}$ & $\begin{array}{l}\text { Café au lait spots, dermal neurofibromas, } \\
\text { axillary/inguinal freckling, ocular hamartomas }\end{array}$ & Relles 2010 [38] \\
\hline \multirow[t]{6}{*}{$S D H B, S D H C$, and $S D H D^{* * *}$} & $\mathrm{SDHB}$ IVS1 $+1 \mathrm{G} \rightarrow \mathrm{T}$ & Paraganglioma and pheochromocytoma & Carney 2002 [39] \\
\hline & $\mathrm{SDHBC} .423+1 \mathrm{G} \rightarrow \mathrm{C}$ & (Carney-Stratakis Syndrome) & McWhinney 2007 [40] \\
\hline & SDHB C.45_46insCC & & \\
\hline & $\mathrm{SDHC} C .43+1 \mathrm{C} \rightarrow \mathrm{T}$ & & \\
\hline & $\mathrm{SDHC}$ IVS5 $+1 \mathrm{G} \rightarrow \mathrm{A}$ & & \\
\hline & SDHD c.57delG & & \\
\hline
\end{tabular}

*Platelet derived growth factor receptor-alpha.

**Neurofibromin 1 .

***Succinate dehydrogenase $(B, C$, and $D)$. 
GIST syndrome. Families have been described that have single base mutations in the tyrosine kinase I domain resulting in a substitution of Glu for Lys (642) [33,34]. A predisposition to GIST was present in these families but not hyperpigmentation or urticaria pigmentosa, providing further support to the fact that specific KIT germline mutations may lead to variable clinical phenotypes.

Mouse models with "knock-in" mutations, representing inherited GIST syndromes, additionally support the slightly different clinical phenotypes associated with specific KIT mutations. Mice with the V558del mutation (corresponding to the human exon 11 deletion mutation) as well as the D818Y mutation (corresponding to human exon 17 missense mutation) had interstitial cell of Cajal hyperplasia and GISTs [41,42]. Only mice with V558del had increased dermal mast cells, a finding not seen in mice with the D818Y mutation. This suggests the specific KIT exon 11 mutation may be required for the feature of urticaria pigmentosa whereas development of GIST may be a more generalized phenomenon, associated with a broad spectrum of KIT activating germline mutations. Despite the suggestion of genotype specific clinical features, variability in patient reporting of additional components of the inherited GIST syndrome may complicate precise genotype-phenotype correlations as suggested in one report [26].

\section{PDGFRA mutations}

Though the majority of described inherited GIST syndromes have been associated with germline KIT mutations, several families with inherited predisposition to GISTs have been described with germline PDGFRA mutations. One French family with five affected individuals was found to have a germline PDGFRA missense mutation $(2675 \mathrm{G}>\mathrm{T})$, resulting in a tyrosine substitution for the highly conserved aspartic amino acid at codon 846 which showed perfect cosegregation with the GIST phenotype in the tested family members [35]. Affected individuals also had large hands whereas those without the mutation, did not. Interestingly, the PDGFRA Asp846Tyr mutation identified in this family is homologous to codon 820, located on the KIT tyrosine kinase II domain, the site of inherited GIST involving a Japanese kindred of six affected family members [32].

Other PDGFRA mutations, in addition to Asp846Tyr, have been associated with inherited GIST. Three sisters who were affected with intestinal neurofibromatosis in an autosomal dominant pattern of inheritance, without other manifestations of neurofibromatosis 1 (NF1) or neurofibromatosis 2 (NF2), underwent genetic screening, and a PDGFRA Y555C mutation, located in the juxtamembrane domain, was identified [36]. The similarity of these tumors' genetic composition and clinical phenotype to GIST led the authors to conclude that intestinal neurofibromatosis is a specific subtype of KIT negative, familial GIST, associated with PDGFRA mutations and not a completely distinct disease. Affected individuals had large hands, a finding similar to other families described with inherited GIST and PDGFRA mutations, though not described in familial GIST associated with KIT germline mutations. None of the other related clinical manifestations of inherited GIST (dysphagia, hyperpigmentation, urticaria pigmentosa) associated with germline KIT mutations was seen in patients with PDGFRA mutations.

A third PDGFRA germline missense mutation (V561D) involving exon 12 was identified in a young female patient with several gastric GISTs [37]. This patient's alternative germline PDGFRA mutation may have resulted in her slightly different phenotype as she was noted to have, in addition to gastric GISTs, multiple lipomas and fibrous tumors of her small intestine. Lipomas and fibrous tumors of the small intestine were not previously part of other families described [35,36] with PDGFRA mutations and predisposition to GIST nor where they a feature of families with KIT germline mutations.

\section{Neurofibromatosis type 1; von Recklinghausen's disease (NF1)}

NF1 is a common genetic disorder occurring in approximately 1 in every 3,000 live births. The disease is classically associated with café au lait spots, multiple dermal neurofibromas, axillary and inguinal freckling, and ocular hamartomas [43]. NF1 is inherited in an autosomal dominant manner, and the mutated NF1 protein encodes the GTPase activating protein neurofibromin.

Patients with NF1 have been felt to be at increased risk of a variety of GI tumors. A previous report reviewing the literature found that 34\% of GI tract malignancies in patients with NF1 were GISTs [38]. NF1 associated GISTs are somewhat different than typical sporadic GISTs as NF1 associated GISTs typically have neither mutated KIT nor PDGFRA genes [44,45]. One series, nevertheless, reported that a small number of NF1 patients did have KIT and PDGFRA mutations [46].

Since the majority of GISTs associated with NF1 mutations do not have $c-K I T$ or PDGFRA mutations, NF1 associated GISTs may have alternative pathogenesis which may result in different clinical outcomes. The majority of the tumors from patients in the series by Miettinen et al. 2006 had small, mitotically inactive tumors, and the majority of patients in this series with long-term follow-up had good prognosis [44]. Whether NF1 associated GISTs arise from a completely KIT independent process or whether the mutated neurofibromin protein indirectly activates KIT pathways carries significant clinical implications. Therapies that directly target KIT such as imatinib may not be effective in patients 
with NF1 associated GIST. Despite the lack of KIT mutations in most cases of NF1 GIST, one case report indicated disease stabilization with sunitinib [47].

\section{Succinate dehydrogenase mutations}

Succinate dehydrogenase (SDH) is an enzyme localized to the inner mitochondrial membrane and is integral to cellular respiration by participating in both the citric acid cycle and the electron transport chain. SDH is composed of four subunits (A-D), and mutations in the SDH genes encoding each subunit have been associated with various human diseases [48]. Not surprisingly, a number of these diseases involve disordered mitochondrial respiration, resulting in severe metabolic and neurologic dysfunction.

In addition to SDH's critical role in cellular respiration, $\mathrm{SDH}$ is believed to function as a tumor suppressor. Mutations in SDH subunits B (SDHB), C (SDHC), and $\mathrm{D}$ (SDHD), in particular, have been associated with familial cancer predisposition syndromes with affected individuals at increased risk for the development of paragangliomas and pheochromocytomas [10]. In 2002, 12 individuals from five unrelated families were found to have developed paragangliomas and GISTs, and the Carney-Stratakis Syndrome (CSS) was described [39].

CSS appears to be an autosomal dominant syndrome with incomplete penetrance characterized by the development of paraganglioma, GIST, or both. CSS has a variable phenotypic expression as demonstrated by a report of monozygotic twins with CSS where one developed a paraganglioma and the other GIST [49]. To better characterize the germline mutations present in patients with CSS, genetic sequencing was performed for six individuals in six unrelated families, and mutations in $S D H B, S D H C$, and $S D H D$, were identified [40]. Differing from most sporadic GISTs, no mutations in KIT or PDGFRA were seen.

Additional recent work has confirmed the important role SDH plays in the pathogenesis of GISTs. A study of 34 GIST patients without KIT or PDGFRA mutations (WT GIST) revealed that four patients (12\%) had SDH germline mutations, even in the absence of a family or personal history of paragangliomas. Further, even in patients without germline $S D H$ mutations, patients with WT GISTs had complete loss or markedly reduced SDHB protein expression compared to patients with KIT mutant GIST. This further suggests the important role of SDH in the pathogenesis of GIST, in addition to cases where a germline mutation in $S D H$ is found [50]. The finding of absent or low levels of SDH protein in patients with CSS was confirmed by a study showing that none of the four patients with CSS had positive immunohistochemical staining for SDHB, even though only one was found to have a germline mutation. This contrasted starkly with KIT and PDGFRA mutant GIST samples which all stained strongly for SDHB [12]. Though mutations in $S D H B, S D H C$, and $S D H D$, have been described most thoroughly, recently two young patients with GIST were found to have detectable mutations in SDHA, representing the first described cases of SDHA inactivation in GIST [51].

\section{Deletions in chromosome 1 involving succinate dehydrogenase $\mathbf{C}$}

Due to associations between SDH mutations and patients with paraganglioma and GIST syndromes, the presence of SDH mutations was evaluated in patients with Carney Triad (CT), a similar, though distinct, syndrome from CSS [52]. CT is felt to be non-hereditary and consists of having at least two of the triad of paraganglioma, GIST, and pulmonary chordoma. CT was first described in 1977 when Carney and colleagues reported seven unrelated women with the triad [14]. In 2007, comparative genomic hybridization studies were performed on 41 tumor samples from 37 patients with $\mathrm{CT}$, and though no tumors had coding sequence mutations of the investigated $S D H$ genes, a number of DNA copy changes were seen [52]. Particularly, deletions of chromosome 1p and 1q12-q21, the site of the SDHC gene, were found. Interestingly, other classic mutations associated with GIST such as KIT and PDGFRA were not found in these tumor specimens from patients with $\mathrm{CT}$. This finding is consistent with results from other studies [15,53], raising the possibility that GISTs in CT arise from alternative pathologic mechanisms from most sporadic GISTs.

Consistent with an alternative genetic and possible pathologic mechanism of tumorigenesis, GISTs in CT behave differently clinically from most sporadic GISTs as they affect young women and have been associated with frequent lymph node metastasis, multifocality, and unpredictable behavior [20]. In a review published in 1999, Carney described a higher rate of gastric GIST and metastatic disease at presentation [29]. How deletions of chromosome $1 \mathrm{p}$ and $1 \mathrm{q}$ (in the region of the $S D H C$ gene) contribute to the alternative clinical behavior of GISTs associated with CT remains to be explained.

\section{Treatment of patients with inherited GIST}

Although various germline mutations have been associated with heterogeneous clinical syndromes, no data currently exist that inherited GIST should be treated differently from its sporadic counterpart. Nevertheless, on a theoretical basis, increasing knowledge of the various germline mutations associated with hereditary GIST suggests that different clinical approaches may ultimately show increased benefit. For example, when GIST is present in patients with paragangliomas (Carney-Stratakis 
Syndrome), due to the lack of mutations in KIT and PDGFRA (WT GIST), these tumors theoretically may be less sensitive to imatinib. This may also be true for inherited GIST associated with NF1 mutations as KIT mutations are only found in small proportions of NF1 GIST. Clinical data are not yet available to address these theoretical speculations.

Inherited GIST associated with CSS has been shown to be related to deficits in SDH, and improved understanding of the mechanisms surrounding SDH regulation may lead to future therapeutic approaches. Unfortunately, patients with advanced WT GIST when treated with imatinib had decreased objective response, time to tumor progression, and overall survival compared to patients with KIT exon 11 mutations [54]. Mutations in SDH and NF1 may explain the non-KIT mediated pathogenesis in patients with WT GIST, and patients with inherited SDH mutations, and possibly NF1 mutations, may ultimately benefit from alternative targeted treatment. The relationship between SDH and NF1 to GIST pathogenesis will first need to be further clarified.

Patients whose GISTs are characterized by a deficiency in SDHB by immunohistochemistry have been described to have a somewhat different clinical course from the majority of GIST patients. Specifically, one study found that deficiency of SDHB was associated with a female predominance, gastric primary location, lymph node involvement, and similar morphology to GIST arising in pediatric patients [55]. Since these patients' GISTs followed a more indolent course, SDHB deficient tumors may ultimately need to be managed differently.

Sunitinib may be particularly helpful for patients with GIST who develop resistance or intolerance to imatinib. A study involving 97 patients with metastatic, imatinibresistant/intolerant GIST, demonstrated the particular efficacy of sunitinib in patients with primary exon 9 and WT GIST [56,57].

\section{Conclusions}

Gastrointestinal stromal tumors are the most common mesenchymal tumor arising in the GI tract, and therapy targeting the molecular abnormalities involved in GIST pathogenesis has been a remarkable success in solid tumor oncology. Improved recognition of the associated clinical features of patients with inherited GIST likely to harbor germline mutations will lead to appropriate genetics evaluation and may influence family members wishing to evaluate their risk. Unlike other cancer predisposition syndromes such as Lynch Syndrome, some of the germline mutations that result in inherited GIST, such as mutations involving KIT and PDGFR genes, produce abnormal proteins that can be inhibited by currently available targeted therapy. Increasing knowledge of novel inherited germline mutations predisposing to
GIST, particularly wild-type inherited GIST, may lead to improved understanding of perturbed molecular pathways in sporadic GIST as well. For instance, the recognition of genetic abnormalities in SDH in GISTs that are not associated with KIT and PDGFRA mutations introduces a new avenue of research that may have relevance for sporadic disease.

\begin{abstract}
Abbreviations
CSS: Carney-Stratakis syndrome; CT: Carney triad; GIST: Gastrointestinal stromal tumor; NF1: Neurofibromatosis-1; NF2: Neurofibromatosis-2; PDGFRA: Platelet derived growth factor receptor-alpha; SEER: Surveillance epidemiology and end results; SDH: Succinate dehydrogenase; WT: Wild type.
\end{abstract}

\section{Competing interests}

The authors declare that they have no competing interests.

\section{Authors' contributions}

MP collected the references and wrote the first draft of the manuscript. MR revised the manuscript and provided intellectual guidance in support of the content of this project. Both authors read and approved the final manuscript.

\section{Authors' information}

MP is a medical oncology fellow in the Melanoma/Sarcoma Oncology Service at Memorial Sloan-Kettering Cancer Center. MR is the clinic director of the Clinical Genetics Service at Memorial Sloan-Kettering Cancer Center and a member of the Breast Cancer Medicine Service.

\section{Acknowledgements}

None.

\section{Author details}

${ }^{1}$ Department of Medicine, Memorial Sloan-Kettering Cancer Center, New York, NY, USA. ${ }^{2}$ Clinical Genetics and Breast Cancer Medicine Services, Memorial Sloan-Kettering Cancer Center, New York, NY, USA. ${ }^{3}$ Weill Cornell Medical College of Cornell University, New York, NY, USA.

Received: 12 August 2011 Accepted: 19 December 2011

Published: 4 October 2012

\section{References}

1. Demetri GD, Benjamin RS, Blanke CD, Blay JY, Casali P, Choi H, Corless CL, Debiec-Rychter M, DeMatteo RP, Ettinger DS, Fisher GA, Fletcher CD, Gronchi A, Hohenberger P, Hughes M, Joensuu H, Judson I, Le Cesne A, Maki RG, Morse M, Pappo AS, Pisters PW, Raut CP, Reichardt P, Tyler DS, Van den Abbeele AD, von Mehren M, Wayne JD, Zalcberg J: NCCN Task Force report: management of patients with gastrointestinal stromal tumor (GIST)-update of the NCCN clinical practice guidelines. J Natl Compr Canc Netw 2007, 5(Suppl 2):S1-S29.

2. Blay JY, Bonvalot $\mathrm{S}$, Casali $\mathrm{P}$, Choi H, Debiec-Richter M, Dei Tos AP, Emile JF, Gronchi A, Hogendoorn PC, Joensuu H, Le Cesne A, McClure J, Maurel J, Nupponen N, Ray-Coquard I, Reichardt P, Sciot R, Stroobants S, van Glabbeke M, van Oosterom A, Demetri GD: Consensus meeting for the management of gastrointestinal stromal tumors. Report of the GIST Consensus Conference of 20-21 March 2004, under the auspices of ESMO. Ann Oncol 2005, 16:566-578.

3. Agaimy A, Hartmann A: Hereditary and non-hereditary syndromic gastointestinal stromal tumours. Pathologe 2010, 31:430-437.

4. Tran T, Davila JA, El-Serag HB: The epidemiology of malignant gastrointestinal stromal tumors: an analysis of 1,458 cases from 1992 to 2000. Am J Gastroenterol 2005, 100:162-168.

5. Nilsson B, Bümming P, Meis-Kindblom JM, Odén A, Dortok A, Gustavsson B, Sablinska K, Kindblom LG: Gastrointestinal stromal tumors: the incidence, prevalence, clinical course, and prognostication in the preimatinib mesylate era-a population-based study in western Sweden. Cancer 2005, 103:821-829.

6. Tryggvason G, Gíslason HG, Magnússon MK, Jónasson JG: Gastrointestinal stromal tumors in Iceland, 1990-2003: the icelandic GIST study, a 
population-based incidence and pathologic risk stratification study. Int J Cancer 2005, 117:289-293.

7. Tzen CY, Wang JH, Huang YJ, Wang MN, Lin PC, Lai GL, Wu CY, Tzen CY: Incidence of gastrointestinal stromal tumor: a retrospective study based on immunohistochemical and mutational analyses. Dig Dis Sci 2007, 52:792-797.

8. Marshall JB, Diaz-Arias AA, Bochna GS, Vogele KA: Achalasia due to diffuse esophageal leiomyomatosis and inherited as an autosomal dominant disorder. Report of a family study. Gastroenterology 1990, 98:1358-1365.

9. Nishida T, Hirota S, Taniguchi M, Hashimoto K, Isozaki K, Nakamura H Kanakura Y, Tanaka T, Takabayashi A, Matsuda H, Kitamura Y: Familial gastrointestinal stromal tumours with germline mutation of the KIT gene. Nat Genet 1998, 19:323-324.

10. Bolland M, Benn D, Croxson M, McCall J, Shaw JF, Baillie T, Robinson B: Gastrointestinal stromal tumour in succinate dehydrogenase subunit B mutation associated familial phaeochromocytoma/paraganglioma. ANZ J Surg 2006, 76:763-764.

11. Carballo M, Roig I, Aguilar F, Pol MA, Gamundi MJ, Hernan I, Martinez-Gimeno M: Novel c-KIT germline mutation in a family with gastrointestinal stromal tumors and cutaneous hyperpigmentation. Am J Med Genet A 2005, 132:361-364.

12. Gaal J, Stratakis CA, Carney JA, Ball ER, Korpershoek E, Lodish MB, Levy I, Xekouki P, van Nederveen FH, den Bakker MA, O'Sullivan M, Dinjens WN, de Krijger RR: SDHB immunohistochemistry: a useful tool in the diagnosis of Carney-Stratakis and Carney triad gastrointestinal stromal tumors. Mod Pathol 2011, 24:147-151

13. Stratakis CA, Carney JA: The triad of paragangliomas, gastric stromal tumours and pulmonary chondromas (Carney triad), and the dyad of paragangliomas and gastric stromal sarcomas (Carney-Stratakis syndrome): molecular genetics and clinical implications. J Intern Med 2009, 266:43-52

14. Carney JA, Sheps SG, Go VL, Gordon H: The triad of gastric leiomyosarcoma, functioning extra-adrenal paraganglioma and pulmonary chondroma. N Engl J Med 1977, 296:1517-1518.

15. Agaimy A, Pelz AF, Corless CL, Wünsch PH, Heinrich MC, Hofstaedter F, Dietmaier W, Blanke CD, Wieacker P, Roessner A, Hartmann A, Schneider-Stock R: Epithelioid gastric stromal tumours of the antrum in young females with the Carney triad: a report of three new cases with mutational analysis and comparative genomic hybridization. Oncol Rep 2007, 18:9-15.

16. Chen CF, Chuang CH, Liu MK, Hsu WH, Lin HJ, Hsieh JS: Clinical, radiologic and pathologic characteristics of the Carney triad: a case report and literature review. Kaohsiung J Med Sci 2010, 26:428-434.

17. Kiser $\mathrm{M}$, Caudle A, von Allmen D: Multicentric paragangliomas associated with Carney triad. Am Surg 2010, 76:216-218.

18. Agaimy A, Carney JA: Lymphatics and D2-40/podoplanin expression in gastrointestinal stromal tumours of the stomach with and without lymph node metastasis: an immunohistochemical study with special reference to the Carney triad. J Clin Pathol 2010, 63:229-234.

19. Qiao GB, Fang Y, Zeng WS, Peng LJ, Huang WJ: Images for diagnosis. An unusual case of Carney triad with high level catecholamine-secreting but no existence of extra-adrenal paraganglioma. Chin Med J (Engl) 2010, 123:510-512.

20. Zhang L, Smyrk TC, Young WF Jr, Stratakis CA, Carney JA: Gastric stromal tumors in Carney triad are different clinically, pathologically, and behaviorally from sporadic gastric gastrointestinal stromal tumors: findings in 104 cases. Am J Surg Pathol 2010, 34:53-64.

21. Song HJ, Kim KM, Choi DI, Park CK: Carney triad in an adult with aggressive behavior: the first case in Korea. Yonsei Med J 2009, 50:709-712.

22. Carney JA: Carney triad: a syndrome featuring paraganglionic, adrenocortical, and possibly other endocrine tumors. J Clin Endocrinol Metab 2009, 94:3656-3662.

23. Sawhney SA, Chapman AD, Carney JA, Gomersall LN, Dempsey OJ: Incomplete Carney triad-a review of two cases. QJM 2009, 102:649-653.

24. Qiao GB, Zeng WS, Peng LJ, Zhong WZ, Fang Y, Huang WJ, Wu YL: Multiple pulmonary chondromas in a young female patient: a component of Carney triad. J Thorac Oncol 2009, 4:751-752.

25. Alberto VO, Kelleher D, Denholm RB, Nutt M, Carney JA: A calcified lung tumour and microcytic anaemia in a young woman: partial expression of the Carney triad. Surgeon 2008, 6:249-251.
26. Robson ME, Glogowski E, Sommer G, Antonescu CR, Nafa K, Maki RG, Ellis N, Besmer $\mathrm{P}$, Brennan $\mathrm{M}$, Offit $\mathrm{K}$ : Pleomorphic characteristics of a germ-line KIT mutation in a large kindred with gastrointestinal stromal tumors, hyperpigmentation, and dysphagia. Clin Cancer Res 2004, 10:1250-1254.

27. Rodriguez FJ, Aubry MC, Tazelaar HD, Slezak J, Carney JA: Pulmonary chondroma: a tumor associated with Carney triad and different from pulmonary hamartoma. Am J Surg Pathol 2007, 31:1844-1853.

28. Jabbour SA, Miller JL: A case of the Carney triad. Endocr Pract 1999, 5:266-268.

29. Carney JA: Gastric stromal sarcoma, pulmonary chondroma, and extraadrenal paraganglioma (Carney Triad): natural history, adrenocortical component, and possible familial occurrence. Mayo Clin Proc 1999, 74:543-552.

30. Beghini A, Tibiletti MG, Roversi G, Chiaravalli AM, Serio G, Capella C, Larizza $L$ : Germline mutation in the juxtamembrane domain of the kit gene in a family with gastrointestinal stromal tumors and urticaria pigmentosa. Cancer 2001, 92:657-662.

31. Maeyama H, Hidaka E, Ota H, Minami S, Kajiyama M, Kuraishi A, Mori H, Matsuda Y, Wada S, Sodeyama H, Nakata S, Kawamura N, Hata S, Watanabe M, lijima Y, Katsuyama T: Familial gastrointestinal stromal tumor with hyperpigmentation: association with a germline mutation of the c-kit gene. Gastroenterology 2001, 120:210-215.

32. Hirota S, Nishida T, Isozaki K, Taniguchi M, Nishikawa K, Ohashi A, Takabayashi A, Obayashi T, Okuno T, Kinoshita K, Chen H, Shinomura Y, Kitamura $Y$ : Familial gastrointestinal stromal tumors associated with dysphagia and novel type germline mutation of KIT gene. Gastroenterology 2002, 122:1493-1499.

33. Isozaki K, Terris B, Belghiti J, Schiffmann S, Hirota S, Vanderwinden JM: Germline activating mutation in the kinase domain of KIT gene in familial gastrointestinal stromal tumors. Am J Pathol 2000, 157:1581-1585.

34. Graham J, Debiec-Rychter M, Corless CL, Reid R, Davidson R, White JD: Imatinib in the management of multiple gastrointestinal stromal tumors associated with a germline KIT K642E mutation. Arch Pathol Lab Med 2007, 131:1393-1396.

35. Chompret A, Kannengiesser $C$, Barrois $M$, Terrier $P$, Dahan $P$, Tursz $T$, Lenoir GM, Bressac-De Paillerets B: PDGFRA germline mutation in a family with multiple cases of gastrointestinal stromal tumor. Gastroenterology 2004, 126:318-321.

36. de Raedt T, Cools J, Debiec-Rychter M, Brems H, Mentens N, Sciot R, Himpens J, de Wever I, Schöffski P, Marynen P, Legius E: Intestinal neurofibromatosis is a subtype of familial GIST and results from a dominant activating mutation in PDGFRA. Gastroenterology 2006 131:1907-1912.

37. Pasini B, Matyakhina L, Bei T, Muchow M, Boikos S, Ferrando B, Carney JA, Stratakis CA: Multiple gastrointestinal stromal and other tumors caused by platelet-derived growth factor receptor alpha gene mutations: a case associated with a germline V561D defect. J Clin Endocrinol Metab 2007, 92:3728-3732

38. Relles D, Baek J, Witkiewicz A, Yeo CJ: Periampullary and duodenal neoplasms in neurofibromatosis type 1: two cases and an updated 20-year review of the literature yielding 76 cases. J Gastrointest Surg 2010, 14:1052-1061.

39. Carney JA, Stratakis CA: Familial paraganglioma and gastric stromal sarcoma: a new syndrome distinct from the Carney triad. Am J Med Genet 2002, 108:132-139.

40. McWhinney SR, Pasini B, Stratakis CA: Familial gastrointestinal stromal tumors and germ-line mutations. N Engl J Med 2007, 357:1054-1056.

41. Sommer G, Agosti V, Ehlers I, Rossi F, Corbacioglu S, Farkas J, Moore M, Manova K, Antonescu CR, Besmer P: Gastrointestinal stromal tumors in a mouse model by targeted mutation of the Kit receptor tyrosine kinase. Proc Natl Acad Sci U S A 2003, 100:6706-6711.

42. Nakai N, Ishikawa T, Nishitani A, Liu NN, Shincho M, Hao H, Isozaki K, Kanda T, Nishida T, Fujimoto J, Hirota S: A mouse model of a human multiple GIST family with KIT-Asp820Tyr mutation generated by a knock-in strategy. J Pathol 2008, 214:302-311.

43. Gutmann DH, Aylsworth A, Carey JC, Korf B, Marks J, Pyeritz RE, Rubenstein A, Viskochil D: The diagnostic evaluation and multidisciplinary management of neurofibromatosis 1 and neurofibromatosis 2 . JAMA 1997, 278:51-57. 
44. Miettinen M, Fetsch JF, Sobin LH, Lasota J: Gastrointestinal stromal tumors in patients with neurofibromatosis 1: a clinicopathologic and molecular genetic study of 45 cases. Am J Surg Pathol 2006, 30:90-96.

45. Kinoshita K, Hirota S, Isozaki K, Ohashi A, Nishida T, Kitamura Y, Shinomura Y, Matsuzawa Y: Absence of c-kit gene mutations in gastrointestinal stromal tumours from neurofibromatosis type 1 patients. J Pathol 2004, 202:80-85.

46. Takazawa Y, Sakurai S, Sakuma Y, Ikeda T, Yamaguchi J, Hashizume Y, Yokoyama S, Motegi A, Fukayama M: Gastrointestinal stromal tumors of neurofibromatosis type I (von Recklinghausen's disease). Am J Surg Pathol 2005, 29:755-763.

47. Kalender ME, Sevinc A, Tutar E, Sirikci A, Camci C: Effect of sunitinib on metastatic gastrointestinal stromal tumor in patients with neurofibromatosis type 1: a case report. World J Gastroentero/ 2007 , 13:2629-2632

48. Oyedotun KS, Lemire BD: The quaternary structure of the Saccharomyces cerevisiae succinate dehydrogenase. Homology modeling, cofactor docking, and molecular dynamics simulation studies. J Biol Chem 2004, 279:9424-9431.

49. Boccon-Gibod L, Boman F, Boudjemaa S, Fabre M, Leverger G, Carney AJ: Separate occurrence of extra-adrenal paraganglioma and gastrointestinal stromal tumor in monozygotic twins: probable familial Carney syndrome. Pediatr Dev Pathol 2004, 7:380-384.

50. Janeway KA, Kim SY, Lodish M, Nosé V, Rustin P, Gaal J, Dahia PL, Liegl B, Ball ER, Raygada M, Lai AH, Kelly L, Hornick UL, O'Sullivan M, de Krijger RR, Dinjens WN, Demetri GD, Antonescu CR, Fletcher JA, Helman L, Stratakis CA: Defects in succinate dehydrogenase in gastrointestinal stromal tumors lacking KIT and PDGFRA mutations. Proc Natl Acad Sci U S A 2011, 108:314-318.

51. Pantaleo MA, Astolfi A, Indio V, Moore R, Thiessen N, Heinrich MC, Gnocchi C, Santini D, Catena F, Formica S, Martelli PL, Casadio R, Pession A, Biasco G: SDHA loss-of-function mutations in KIT-PDGFRA wild-type gastrointestinal stromal tumors identified by massively parallel sequencing. J Natl Cancer Inst 2011, 103:983-987.

52. Matyakhina L, Bei TA, McWhinney SR, Pasini B, Cameron S, Gunawan B, Stergiopoulos SG, Boikos S, Muchow M, Dutra A, Pak E, Campo E, Cid MC, Gomez F, Gaillard RC, Assie G, Füzesi L, Baysal BE, Eng C, Carney JA Stratakis CA: Genetics of carney triad: recurrent losses at chromosome 1 but lack of germline mutations in genes associated with paragangliomas and gastrointestinal stromal tumors. J Clin Endocrinol Metab 2007, 92:2938-2943

53. Knop S, Schupp M, Wardelmann E, Stueker D, Horger MS, Kanz L, Einsele H, Kroeber SM: A new case of Carney triad: gastrointestinal stromal tumours and leiomyoma of the oesophagus do not show activating mutations of KIT and platelet-derived growth factor receptor alpha. J Clin Pathol 2006, 59:1097-1099.

54. Heinrich MC, Owzar K, Corless CL, Hollis D, Borden EC, Fletcher CD, Ryan CW, von Mehren M, Blanke CD, Rankin C, Benjamin RS, Bramwell VH, Demetri GD, Bertagnolli MM, Fletcher JA: Correlation of kinase genotype and clinical outcome in the North American Intergroup Phase III Trial of imatinib mesylate for treatment of advanced gastrointestinal stromal tumor: CALGB 150105 Study by Cancer and Leukemia Group B and Southwest Oncology Group. J Clin Oncol 2008, 26:5360-5367.

55. Gill AJ, Chou A, Vilain R, Clarkson A, Lui M, Jin R, Tobias V, Samra J, Goldstein D, Smith C, Sioson L, Parker N, Smith RC, Sywak M, Sidhu SB, Wyatt JM, Robinson BG, Eckstein RP, Benn DE, Clifton-Bligh RJ: Immunohistochemistry for SDHB divides gastrointestinal stromal tumors (GISTs) into 2 distinct types. Am J Surg Pathol 2010, 34:636-644.

56. Heinrich MC, Maki RG, Corless CL, Antonescu CR, Harlow A, Griffith D, Town A, McKinley A, Ou WB, Fletcher JA, Fletcher CD, Huang X, Cohen DP, Baum CM, Demetri GD: Primary and secondary kinase genotypes correlate with the biological and clinical activity of sunitinib in imatinib resistant gastrointestinal stromal tumor. J Clin Oncol 2008, 26:5352-5359.

57. Wozniak A, Floris G, Debiec-Rychter M, Sciot R, Schöffski P: Implications of mutational analysis for the management of patients with gastrointestinal stromal tumors and the application of targeted therapies. Cancer Invest 2010, 28:839-848.

doi:10.1186/2045-3329-2-16

Cite this article as: Postow and Robson: Inherited gastrointestinal stromal tumor syndromes: mutations, clinical features, and therapeutic implications. Clinical Sarcoma Research 2012 2:16.

\section{Submit your next manuscript to BioMed Central and take full advantage of:}

- Convenient online submission

- Thorough peer review

- No space constraints or color figure charges

- Immediate publication on acceptance

- Inclusion in PubMed, CAS, Scopus and Google Scholar

- Research which is freely available for redistribution 